\title{
EFFECT OF COMPOST/NPK AND BIOFERTILIZATION TREATMENTS ON VEGETATIVE GROWTH, YIELD AND HERB NPK\% OF FENNEL PLANTS
}

\author{
F.S. Badran ${ }^{*}$, E.T. Ahmed ${ }^{*}$ E.A. El-Ghadban ${ }^{* *}$ and A.M. Ayyat ${ }^{* * *}$ \\ * Hort. Dept., Fac. Agric., Minia Univ., Egypt. \\ ** Medicinal and Aromatic Plants Res. Dept., Hort. Res. Inst., ARC, Giza, Egypt. \\ *** Fac. Agric., Beni-Suef Univ., Egypt.
}

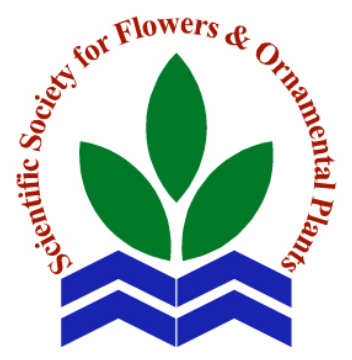

ABSTRACT: A field experiment was conducted during the two successive seasons of 2012/2013 and 2013/2014 to study the effect of compost/NPK and biofertilization treatments on vegetative growth, yield and herb NPK \% of fennel plants.

Obtained results revealed that the best vegetative growth characters (plant height, stem diameter, number of main branches and herb dry weight), yield parameters (number of umbels and fruit yield per plant and per fed) and herb \% of NP and K values were obtained due to the use of the full dose of mineral NPK, $1 / 4$ compost $+3 / 4$ NPK dose or $1 / 2$ compost $+1 / 2$ NPK dose with no significant differences being detected between such three fertilization treatments. Concerning biofertilization treatments, all of the prementioned growth, yield and chemical traits were considerably augmented due to the dual treatment (Minia Azotein

Scientific J. Flowers \& + phosphorein) followed by Minia Azotein, while phosphorein gave Ornamental Plants, the least values. In regard to the interaction gave between the, two 4(2):175-185 (2017). involved factors, the highest growth, yield and chemical composition

Received:

$15 / 3 / 2017$

Accepted: 3/4/2017 values were given by fertilizing fennel plants with the full dose of mineral NPK, $1 / 4$ compost $+3 / 4$ NPK or $1 / 2$ compost $+1 / 2$ NPK in combination with dual biofertilizer treatments (Minia Azotein + phosphorein).

There for, it could be advised from the economical and environmental point of view, to supply fennel plants with the treatment of $1 / 2$ compost $+1 / 2$ NPK dose in combination with both Minia Azotein plus phosphorein in order to obtain the best fruit yield of fennel plants.

Key words: Foeniculum vulgare, compost, NPK, biofertilization, vegetative growth.

\section{INTRODUCTION}

Fennel (Foeniculum vulgare, Miller) plant is one of the most common and widely cultivated aromatic and medicinal plants in middle Egypt Governorates such as BeniSuef, Minia and Assuit. It is a 120-180 cm long winter annual herb belonging to Fam. Apiaceae. Fennel is originally native to Mediterranean Sea region from where its cultivation spread out to Europe and Latin America Countries. The fruits which are the used part of fennel plant contain 3.5-5\% volatile oil with the most important components being anethole and fenchone. The fruits are commonly used in medicinal folklore and bakery and the volatile oil is involved in many pharmaceutical purposes and food industry.

Different authors indicated the efficiency of organic fertilization, with various sources, in increasing vegetative growth, yield and/or herb N,P and $\mathrm{K} \%$ of different aromatic seed plants, namely, caraway (Abd El-Latif, 2002 


\section{F.S. Badran et al.}

and Abd El-Naeem, 2008); fennel (Badran and Safwat, 2004 and Tanious, 2008); cumin (Badran et al., 2007 and Seghatoleslami, 2013); coriander (Abdalla, 2009); Nigella sativa (Mahmoud, 2009) and dill (Hassan et al., 2010). Concerning mineral NPK fertilization, a good number of investigators insured the role of such treatment on the same growth, yield and chemical composition, such as Badran et al. (2001), Khattab and Helmy (2003), Salah-Eldeen (2005) and Tanious (2008) on fennel; Badran et al. (2003) on anise; Abd El-Naeem (2008) on caraway; Kenawy (2010) on Ammi visnaga and Badran et al. (2011) on coriander. Meanwhile, Badran et al. (2001) and Tanious (2008) on fennel; Abd El-Latif (2002) and Abd El-Naeem (2008) on caraway; Safwat and Badran (2002) and Shalateet (2006) on cumin; Badran et al. (2012) on Nigella sativa and Rekaby (2013) on coriander reported the positive influence of N-fixing and/or P- dissolving bacteria.

Therefore, the present study was designed to find out the most suitable organic / mineralNPK / biofertilization combined treatment for attaining the bet vegetative growth characters and fruits yield of fennel plants.

\section{MATERIALS AND METHODS}

The present investigation was conducted at Mattay, Minia, Egypt during 2012/2013 and 2013/2014 seasons to study the effect of compost/NPK and biofertilizer treatments on vegetative growth, fruit yield and $\mathrm{N}, \mathrm{P}$ and $\mathrm{K}$ herb \% of fennel plants.

Fruits of fennel were sown on the last week of Oct. of both seasons in $3 \times 3.60$ meter plots with $60 \mathrm{~cm}$ distance between the rows and $50 \mathrm{~cm}$ between hills within each row. So, each plot contained 6 rows and 36 hills (2 plants/hill). Plants were thinned twice, 3 weeks from planting date and 2 weeks followed as usual. Physical and chemical properties of the soil are shown in Table (a).

A complete randomized block design following the split-plot arrangement, in three replicates, was executed in this experiment with six compost/NPK treatments in the main plots (A) i.e. control, compost (7.5 ton/fed), $3 / 4$ compost $+1 / 4$ NPK, $1 / 2$ compost + $1 / 2$ NPK, $1 / 4$ compost $+3 / 4$ NPK and full dose of NPK. The full dose of mineral NPK was added at the rate of $200 \mathrm{~kg} / \mathrm{fed}$ ammonium nitrate, 33.5\% N; $150 \mathrm{~kg} /$ fed calcium superphosphate, $15.5 \% \mathrm{P}_{2} \mathrm{O}_{5}$ and $100 \mathrm{~kg} / \mathrm{fed}$ potassium sulphate, $48.55 \mathrm{~K}_{2} \mathrm{O}$. While the full dose of compost (Compost El-Neel) was added at the rate of 7.5 ton/fed, with physical and chemical properties shown in Table (b).

The sub-plots (B) were control, Minia Azotein, phosphorein and Minia Azotein plus phosphorein. The mineral $\mathrm{N}$ and $\mathrm{K}$ fertilizer amounts, for each treatment were divided into 3 batches and added after the last thinning and every three weeks thereafter. While compost and phosphorus fertilizer were added during soil preparation.

Table a. Physical and chemical analysis of the soil.

\begin{tabular}{|c|c|c|c|c|}
\hline Characters & Value & Characters & & Value \\
\hline Soil type & $\begin{array}{l}\text { Clay } \\
\text { loam }\end{array}$ & Total N (\%) & & 0.06 \\
\hline Sand (\%) & 31.70 & Avail. P (\%) & & 8.90 \\
\hline Silt (\%) & 25.60 & Exch. K (mg/1 & $00 \mathrm{~g})$ & 1.46 \\
\hline Clay (\%) & 42.70 & & $\mathbf{F e}$ & 5.10 \\
\hline Org. Matt. (\%) & 1.08 & DTPA & $\mathrm{Cu}$ & 1.29 \\
\hline $\mathrm{Ca} \mathrm{CO} \mathrm{CO}_{3}(\%)$ & 4.18 & Extr. (ppm) & Zn & 1.85 \\
\hline pH (1 : 2.5) & 7.86 & & Mn & 11.52 \\
\hline E.C. $(\mathrm{mmhos} / \mathrm{cm})$ & 1.08 & & & \\
\hline
\end{tabular}

Table b. Physical and chemical properties of the used compost.

\begin{tabular}{|c|c|c|c|}
\hline Properties & Value & Properties & Value \\
\hline Dry weight of $1 \mathrm{~m}^{3}$ & $450 \mathrm{~kg}$ & $\mathrm{C} / \mathrm{N}$ ratio & $18.5-14.1$ \\
\hline Fresh weight of $1 \mathrm{~m}^{3}$ & $650-700 \mathrm{~kg}$ & $\mathrm{NaCl}(\%)$ & 1.1- 1.75 \\
\hline Moisture (\%) & $25-30$ & Total P (\%) & $0.5-0.75$ \\
\hline pH (1:10) & 7.5- 8 & Total K (\%) & $0.8-1.0$ \\
\hline E.C. (mmhos/cm) & $2-4$ & Fe (ppm) & $150-200$ \\
\hline Total N (\%) & $1-1.4$ & Mn (ppm) & $25-56$ \\
\hline Org. matter ( \%) & $32-34$ & $\mathrm{Cu}(\mathrm{ppm})$ & $75-150$ \\
\hline Org. carbon \% & 18.5-19.7 & Zn ppm & $150-225$ \\
\hline
\end{tabular}


The two biofertilizers, Minia Azotein and phosphorein were applied to the soil twice, after 6 and 10 weeks from planting date, at the rate of $50 \mathrm{ml} /$ plant of each biofertilizer, and then plants were irrigated immediately.

Data were recorded for plant height $(\mathrm{cm})$, stem diameter $(\mathrm{cm})$, number of main branches/ plant, herb dry weight (g/plant), number of umbels/ plant and fruit yield(g/ plant and $\mathrm{kg} / \mathrm{fed}$ ). In addition herb $\mathrm{N}, \mathrm{P}$ and $\mathrm{K} \%$ were determined according to Wilde et al. (1985), Chapman and Pratt (1975) and Cottenie et al. (1982), respectively. Obtained data were statically analyzed following the L.S.D. method at 5\% according to MSTATC (1986).

\section{RESULTS}

\section{Vegetative Growth Characters:}

Data obtained in Table (1) indicated that the four tested vegetative growth characters, plant height, stem diameter, branches number/plant and herb dry weight/plant were considerably increased, in both seasons, due to all five compost and/or mineral NPK fertilization treatments in comparison with those of control treatment. However, the three treatments of $1 / 2$ compost $+1 / 2$ NPK, $1 / 4$ compost $+3 / 4$ NPK and full dose of NPK were capable of producing significant in the two seasons, compared to control treatment. It was interesting to find out that such three superior treatments were statistically equal, in both season, in giving the tallest plants, thickest stems, more branches number and heaviest herb dry weight/ plant. Numerically, the increase in plant height, stem diameter, branches number and herb dry weight/ plant, due to these three treatments, respectively, over control treatments, reached 15.7, 18.5, and 20.8\%; 62.6, 72.7 and 84.2\%; 50.2, 70.1 and 89.05 and 21.5, 32.9, and 39.45 in the first season with almost identical trend in the second season as clearly shown in Table (1).

The role of organic fertilization in augmenting vegetative growth traits was also observed by Badran and Safwat (2004) and Tanious (2008) on fennel; Abdalla (2009) on coriander; Mahmoud (2009) on Nigella sativa and Hassan et al. (2010) on dill. While that of mineral NPK was revealed by Badran et al. (2001) and Khattab and Helmy (2003) on fennel; Badran et al. (2003) on anise; Kenawy (2010) on Ammi visnaga and Badran et al. (2011) on coriander.

Concerning biofertilization treatments, the four vegetative growth characters, namely, plant height, stem diameter, branches number and herb dry weight/plant, were increased, in the two seasons, due to Minia Azotein, phosphorein or both of them in combination with control treatment. However, the differences were significant only for stem diameter and number of branches, (Table, 1). Among the three biofertilization treatments, the dual one (Minia Azotein + phosphorein) gave the best results, followed by Minia Azotein, while phosphorein treatment gave the least values and these results were almost identical in both first and second seasons.

On the line with these results were those revealed on different aromatic fruit plants such as fennel (Badran et al., 2001 and Tanious, 2008); caraway (Abd El-Latif, 2002); cumin (Safwat and Badran, 2002) and coriander (Rekaby, 2013).

The interaction between compost/NPK and biofertilization treatments was significant, in the two seasons, for each of plant height, stem diameter, branch number and herb dry weight/plant as shown in Table (1). The best overall results, for the four vegetative growth traits were obtained due to supplying fennel plants with full dose of NPK and $1 / 2$ compost, in combination with dual biofertilization treatment. No significant differences, in general, were detected between such three combined treatments. So, it is advisable, from the economical and environmental point of view, to fertilize fennel plants with $1 / 2$ compost $+1 / 2$ NPK in combination with the dual biofertilization (Minia Azotein + phosphorein) treatment, (Table, 1). 
Table 1. Effect of compost/NPK and biofertilization treatments on vegetative growth characters of fennel plants during 2012/2013 and 2013/2014 seasons.

\begin{tabular}{|c|c|c|c|c|c|c|c|c|c|c|}
\hline \multirow{2}{*}{$\begin{array}{c}\text { Compost/NPK } \\
\text { Treatments } \\
\text { (A) }\end{array}$} & \multicolumn{10}{|c|}{ Biofertilizer (B) } \\
\hline & $\begin{array}{c}\text { Control } \\
\text { (zero) }\end{array}$ & $\begin{array}{l}\text { M.A. } \\
\text { irst sea }\end{array}$ & $\begin{array}{l}\text { Phos. } \\
\text { son (20) }\end{array}$ & $\begin{array}{l}\text { M.A.+ } \\
\text { Phos. } \\
\text { 12/2013) }\end{array}$ & $\begin{array}{l}\text { Mean } \\
\text { (A) }\end{array}$ & $\begin{array}{c}\text { Control } \\
\text { (zero) }\end{array}$ & $\begin{array}{l}\text { M.A. } \\
\text { Second }\end{array}$ & $\begin{array}{c}\text { Phos. } \\
\text { season (20 }\end{array}$ & $\begin{array}{l}\text { M.A.+ } \\
\text { Phos. } \\
\text { 13/2014) }\end{array}$ & $\begin{array}{c}\text { Mean } \\
\text { (A) }\end{array}$ \\
\hline & \multicolumn{10}{|c|}{ Plant height $(\mathbf{c m})$} \\
\hline Control (zero) & 151.4 & 152.6 & 152.0 & 158.7 & 153.7 & 152.4 & 156.1 & 156.0 & 160.7 & 156.3 \\
\hline Compost 7.5ton/fed & 163.2 & 167.6 & 167.4 & 168.2 & 166.6 & 163.3 & 165.8 & 165.1 & 172.4 & 166.7 \\
\hline 3/4 Compost + 1/4 NPK & 170.8 & 175.6 & 175.2 & 176.7 & 174.6 & 173.7 & 175.0 & 174.4 & 175.6 & 174.6 \\
\hline $1 / 2$ Compost $+1 / 2$ NPK & 176.8 & 177.6 & 177.2 & 179.8 & 177.9 & 177.0 & 178.1 & 177.2 & 179.8 & 178.0 \\
\hline $1 / 4$ Compost $+3 / 4$ NPK & 180.9 & 182.8 & 181.9 & 183.1 & 182.1 & 180.9 & 181.8 & 181.3 & 182.3 & 181.6 \\
\hline Full dose of NPK & 184.2 & 185.3 & 184.8 & 186.5 & 185.2 & 183.7 & 185.5 & 184.3 & 186.2 & 184.9 \\
\hline Mean (B) & 171.2 & 173.6 & 173.1 & 175.5 & & 171.9 & 173.7 & 172.9 & 176.2 & \\
\hline \multirow[t]{2}{*}{ L.S.D. at $5 \%$} & \multicolumn{2}{|c|}{ A: $9.3 \quad 1$} & N.S & \multicolumn{2}{|c|}{ AB: 19.8} & \multicolumn{2}{|c|}{ A: 8.1} & B: N.S & \multicolumn{2}{|c|}{ AB: 11.2} \\
\hline & \multicolumn{10}{|c|}{ Stem diameter $(\mathrm{cm})$} \\
\hline Control (zero) & 1.35 & 1.38 & 1.36 & 1.48 & 1.39 & 1.32 & 1.46 & 1.39 & 1.50 & 1.42 \\
\hline Compost 7.5ton/fed & 1.52 & 1.63 & 1.56 & 1.71 & 1.61 & 1.72 & 1.86 & 1.82 & 1.92 & 1.83 \\
\hline $3 / 4$ Compost $+1 / 4$ NPK & 1.68 & 2.01 & 1.86 & 2.17 & 1.93 & 2.28 & 2.42 & 2.38 & 2.56 & 2.41 \\
\hline $1 / 2$ Compost $+1 / 2$ NPK & 2.16 & 2.29 & 2.26 & 2.32 & 2.26 & 2.49 & 2.62 & 2.55 & 2.69 & 2.59 \\
\hline $1 / 4$ Compost $+3 / 4$ NPK & 2.29 & 2.46 & 2.35 & 2.50 & 2.40 & 2.58 & 2.71 & 2.69 & 2.74 & 2.68 \\
\hline Full dose of NPK & 2.48 & 2.59 & 2.54 & 2.61 & 2.56 & 2.75 & 2.84 & 2.80 & 2.85 & 2.81 \\
\hline Mean (B) & 1.91 & 2.06 & 1.98 & 2.13 & & 2.12 & 2.31 & 2.27 & 2.39 & \\
\hline \multirow[t]{2}{*}{ L.S.D. at $5 \%$} & \multicolumn{3}{|c|}{ A: $0.45 \quad$ B: } & \multicolumn{2}{|c|}{ AB: 0.44} & \multicolumn{2}{|c|}{ A: 0.42} & B: 0.15 & \multicolumn{2}{|c|}{ AB: 0.37} \\
\hline & \multicolumn{10}{|c|}{ Number of main branches } \\
\hline Control (zero) & 5.56 & 6.33 & 6.11 & 6.78 & 6.19 & 5.11 & 6.22 & 5.67 & 6.33 & 5.83 \\
\hline Compost 7.5ton/fed & 7.33 & 7.78 & 7.33 & 8.33 & 7.69 & 7.00 & 8.00 & 7.33 & 8.11 & 7.61 \\
\hline $3 / 4$ Compost $+1 / 4$ NPK & 7.66 & 8.34 & 8.67 & 9.22 & 8.47 & 8.22 & 8.67 & 8.33 & 9.33 & 8.08 \\
\hline $1 / 2$ Compost $+1 / 2$ NPK & 9.00 & 9.33 & 9.22 & 9.66 & 9.30 & 9.00 & 9.67 & 9.14 & 10.33 & 9.54 \\
\hline $1 / 4$ Compost $+3 / 4$ NPK & 10.11 & 10.67 & 10.14 & 11.20 & 10.53 & 10.13 & 11.00 & 10.33 & 11.24 & 10.68 \\
\hline Full dose of NPK & 11.34 & 11.78 & 11.67 & 12.00 & 11.70 & 11.33 & 12.22 & 12.00 & 12.67 & 12.06 \\
\hline Mean (B) & 8.50 & 9.03 & 8.86 & 9.53 & & 8.47 & 9.30 & 8.80 & 9.67 & \\
\hline \multirow[t]{2}{*}{ L.S.D. at $5 \%$} & \multicolumn{2}{|c|}{ A: 2.94} & B: 0.91 & \multicolumn{2}{|c|}{ AB: 2.23} & \multicolumn{2}{|c|}{ A: 3.01} & B: 0.97 & \multicolumn{2}{|c|}{ AB: 2.38} \\
\hline & \multicolumn{10}{|c|}{ Herb dry weight/plant (g) } \\
\hline Control (zero) & 36.40 & 38.47 & 38.07 & 41.45 & 38.60 & 34.99 & 38.90 & 38.17 & 41.40 & 38.37 \\
\hline Compost 7.5ton/fed & 41.62 & 42.40 & 42.17 & 43.15 & 42.34 & 41.53 & 43.47 & 43.30 & 43.60 & 42.98 \\
\hline $3 / 4$ Compost $+1 / 4$ NPK & 42.22 & 44.45 & 43.65 & 46.23 & 44.14 & 43.82 & 44.17 & 43.95 & 45.80 & 44.43 \\
\hline $1 / 2$ Compost $+1 / 2$ NPK & 45.73 & 47.17 & 46.40 & 48.20 & 46.88 & 46.50 & 47.93 & 47.16 & 48.40 & 47.50 \\
\hline $1 / 4$ Compost $+3 / 4$ NPK & 49.90 & 51.83 & 51.02 & 52.42 & 51.29 & 49.33 & 52.07 & 51.17 & 52.33 & 51.23 \\
\hline Full dose of NPK & 52.67 & 54.03 & 53.45 & 55.05 & 53.80 & 53.52 & 55.05 & 54.86 & 57.04 & 55.12 \\
\hline Mean (B) & 44.76 & 46.39 & 45.79 & 47.75 & & 44.95 & 46.93 & 46.44 & 48.10 & \\
\hline L.S.D. at $5 \%$ & A: 8.08 & & : N.S & AB: & 8.58 & A: 8.75 & & B: N.S & AB: & 9.43 \\
\hline
\end{tabular}


Yield and Yield Components Parameters:

Number of umbels/plant and fruit yield per plant and per fed of fennel plants were augmented in both seasons as a result of using all five compost/ NPK treatments over those of control treatment with significant differences for some of the tested treatments as shown in Table (2). Among the five examined treatments, full dose of NPK, followed by $1 / 4$ compost $+3 / 4$ NPK and $1 / 2$ compost $+1 / 2$ NPK treatments gave the highest number of umbels/plant and heaviest fruit yield per plant and per fed. The increase in fruit yield per fed due to these three treatments, respectively came to $88.3,77.0$ and $61.6 \%$ in the first season and 104.2, 96.7 and $74.9 \%$ in the second season. No significant differences were existed, in both seasons, for fruit yield per plant and per fed among such three superior treatments as obviously illustrated in Table (2).

In agreement with these results, concerning organic fertilization, were the findings of Abd El-Latif (2002) and AbdElnaeem (2008) on caraway; Badran et al. (2007) and Seghatoleslami (2013) on cumin and Tanious (2008) on fennel. While, Badran et al. (2001), Khattab and Helmy (2003), Salah-Eldeen (2005) and Tanious (2008) on fennel and Abd El-Naeem (2008) on caraway insured the efficiency of mineral NPK fertilizers in augmenting fruit yield.

All three biofertilization treatments (Minia Azotein, phosphorein and both of them) increased the three studied parameters, number of umbels/plant and fruit yield per plant and fed with significant differences for the last two traits in comparison with control treatment in both seasons, (Table, 2). The highest values, for the three tested parameters, were obtained from the dual treatment, followed by Minia Azotein then phosphorein. The same trend of results was observed in both first and second seasons.

Different investigators pointed out the role of biofertilizer in augmenting fruit yield of aromatic seed plants such as Badran et al. (2001), Safwat and Badran (2002), Abd-
Elnaeem (2008), Badran et al. (2012) and Rekaby (2013) on fennel, cumin, caraway, black cumin and coriander, respectively.

Table (2) shows that the interaction between factor A (compost/NPK) and factor B (biofertilizers), for number of umbels/ plant and fruit yield per plant and per fed, was significant in both seasons. Were supplied with full dose of NPK in combination with both Minia Azotein + phosphorein. However, this superior treatment was statistically equal to that one received $1 / 2$ compost $+1 / 2$ NPK in combination with the same dual fertilization treatment as shown in Table (2).

Nitrogen, phosphorus and potassium \% in the herb:

The herb $\mathrm{N}, \mathrm{P}$ and $\mathrm{K}$ percent were significantly increased, in both seasons, due to majority of compost/NPK fertilization treatments as indicated in Table (3). The highest values for the three nutrients were obtained, in descending order, due to full dose of NPK, $1 / 4$ compost $+3 / 4$ NPK, $1 / 2$ compost $+1 / 2$ NPK, $3 / 4$ compost $+1 / 4$ NPK and full dose of compost ( 7.5 ton/fed). It is worth to mention that the differences between the first three previously mentioned treatments, for $\mathrm{N}, \mathrm{P}$ and $\mathrm{K} \%$ in both seasons, did not reach the level of significancy as shown in Table (3).

The role of organic fertilization in promoting $\mathrm{N}, \mathrm{P}$ and $\mathrm{K} \%$ was given by Abd El-Latif (2002) and Abd El-Naeem (2008) on caraway; Abdalla (2009) on coriander; Mahmoud (2009) on Nigella sativa and Hassan et al. (2010) on dill. While that of mineral NPK was revealed by Badran et al. (2003) on anise; Salah-Eldeen (2005) and Tanious (2008) on fennel; Abd El-Naeem (2008) on caraway and Kenawy (2010) on Ammi visnaga.

Obtained data show significant differences among the four biofertilization treatments except phosphorus and potassium 5 in the second season, (Table, 3). However, all of the three examined treatments (Minia Azotein, phosphorein and Minia Azotein + 


\section{F.S. Badran et al.}

Table 2. Effect of compost/ NPK and biofertilization treatments on fruit yield characters of fennel plants during 2012/2013 and 2013/2014 seasons.

\begin{tabular}{|c|c|c|c|c|c|c|c|c|c|c|}
\hline \multirow{3}{*}{$\begin{array}{c}\text { Compost/NPK } \\
\text { Treatments } \\
\text { (A) }\end{array}$} & \multicolumn{10}{|c|}{ Biofertilizer (B) } \\
\hline & $\begin{array}{c}\text { Control } \\
\text { (zero) }\end{array}$ & M.A. & & $\begin{array}{l}\text { M.A.+ } \\
\text { Phos. }\end{array}$ & $\begin{array}{l}\text { Mean } \\
\text { (A) }\end{array}$ & $\begin{array}{c}\text { Control } \\
\text { (zero) }\end{array}$ & M.A. & Phos. & $\begin{array}{l}\text { M.A.+ } \\
\text { Phos. }\end{array}$ & $\begin{array}{c}\text { Mean } \\
\text { (A) }\end{array}$ \\
\hline & \multicolumn{5}{|c|}{ First season $(2012 / 2013)$} & \multicolumn{5}{|c|}{ Second season $(2013 / 2014)$} \\
\hline & \multicolumn{10}{|c|}{ Number of umbels/plant } \\
\hline Control (zero) & 16.67 & 18.44 & 17.89 & 19.22 & 18.22 & 24.78 & 26.33 & 25.00 & 27.33 & 25.86 \\
\hline Compost 7.5ton/fed & 21.33 & 23.11 & 22.67 & 24.22 & 22.83 & 27.56 & 28.11 & 27.89 & 28.67 & 28.06 \\
\hline 3/4 Compost + 1/4 NPK & 24.89 & 25.78 & 25.22 & 26.44 & 25.58 & 29.22 & 30.44 & 29.56 & 31.22 & 30.11 \\
\hline $1 / 2$ Compost $+1 / 2$ NPK & 27.89 & 29.55 & 28.34 & 32.78 & 29.64 & 32.22 & 34.56 & 34.22 & 35.11 & 34.03 \\
\hline $1 / 4$ Compost + 3/4 NPK & 34.00 & 34.89 & 34.33 & 36.67 & 34.97 & 39.22 & 41.17 & 40.89 & 42.67 & 40.99 \\
\hline Full dose of NPK & 36.78 & 37.45 & 37.00 & 38.78 & 37.50 & 43.45 & 45.00 & 43.89 & 46.05 & 44.60 \\
\hline Mean (B) & 26.93 & 28.20 & 27.58 & 29.69 & & 32.74 & 34.27 & 33.57 & 35.18 & \\
\hline \multirow[t]{2}{*}{ L.S.D. at $5 \%$} & \multicolumn{2}{|c|}{ A: 8.68} & B: N.S & \multicolumn{2}{|c|}{ AB: 12.75} & \multicolumn{2}{|c|}{ A: 7.87} & B: N.S & \multicolumn{2}{|c|}{ AB: 11.27} \\
\hline & \multicolumn{10}{|c|}{ Fruit yield/plant (g) } \\
\hline Control (zero) & 21.62 & 24.28 & 23.40 & 26.23 & 23.88 & 19.83 & 23.97 & 23.92 & 24.70 & 23.10 \\
\hline Compost 7.5ton/fed & 28.40 & 30.92 & 30.38 & 31.75 & 30.36 & 29.38 & 32.22 & 31.33 & 33.35 & 31.57 \\
\hline 3/4 Compost + 1/4 NPK & 32.10 & 35.60 & 35.03 & 36.83 & 34.89 & 34.47 & 36.22 & 34.93 & 37.58 & 35.80 \\
\hline $1 / 2$ Compost $+1 / 2$ NPK & 36.92 & 38.45 & 37.73 & 41.40 & 38.63 & 37.83 & 40.47 & 40.08 & 43.27 & 40.41 \\
\hline $1 / 4$ Compost + 3/4 NPK & 41.15 & 42.72 & 41.53 & 43.80 & 42.30 & 43.97 & 45.65 & 45.22 & 46.83 & 45.42 \\
\hline Full dose of NPK & 43.65 & 45.45 & 44.38 & 46.47 & 44.98 & 46.52 & 47.13 & 46.95 & 48.00 & 47.15 \\
\hline Mean (B) & 33.97 & 36.24 & 35.41 & 37.74 & & 35.33 & 37.61 & 37.07 & 38.95 & \\
\hline \multirow[t]{2}{*}{ L.S.D. at $5 \%$} & \multicolumn{2}{|c|}{ A: $7.38 \quad \mathrm{E}$} & B: 3.17 & \multicolumn{2}{|c|}{ AB: 7.76} & \multicolumn{2}{|c|}{ A: 7.47} & B: 3.49 & \multicolumn{2}{|c|}{ AB: 8.55} \\
\hline & \multicolumn{10}{|c|}{ Fruit yield/feddan (kg) } \\
\hline Control (zero) & 649 & 729 & 702 & 787 & 717 & 595 & 719 & 718 & 741 & 693 \\
\hline Compost 7.5ton/fed & 852 & 928 & 912 & 953 & 911 & 882 & 967 & 940 & 1001 & 947 \\
\hline $3 / 4$ Compost + 1/4 NPK & 963 & 1068 & 1051 & 1105 & 1047 & 1034 & 1087 & 1057 & 1128 & 1076 \\
\hline $1 / 2$ Compost $+1 / 2$ NPK & 1108 & 1154 & 1132 & 1242 & 1159 & 1135 & 1214 & 1203 & 1298 & 1212 \\
\hline $1 / 4$ Compost + 3/4 NPK & 1235 & 1282 & 1246 & 1314 & 1269 & 1319 & 1370 & 1357 & 1405 & 1363 \\
\hline Full dose of NPK & 1310 & 1364 & 1332 & 1394 & 1350 & 1396 & 1414 & 1409 & 1440 & 1415 \\
\hline Mean (B) & 1019 & 1087 & 1062 & 1132 & & 1060 & 1129 & 1114 & 1168 & \\
\hline L.S.D. at $5 \%$ & A: 206 & & B: 97 & & & A: 226 & & 101 & & 247 \\
\hline
\end{tabular}


Table 3. Effect of compost/ NPK and biofertilization treatments on NPK percentage of fennel plants during $2012 / 2013$ and $2013 / 2014$ seasons.

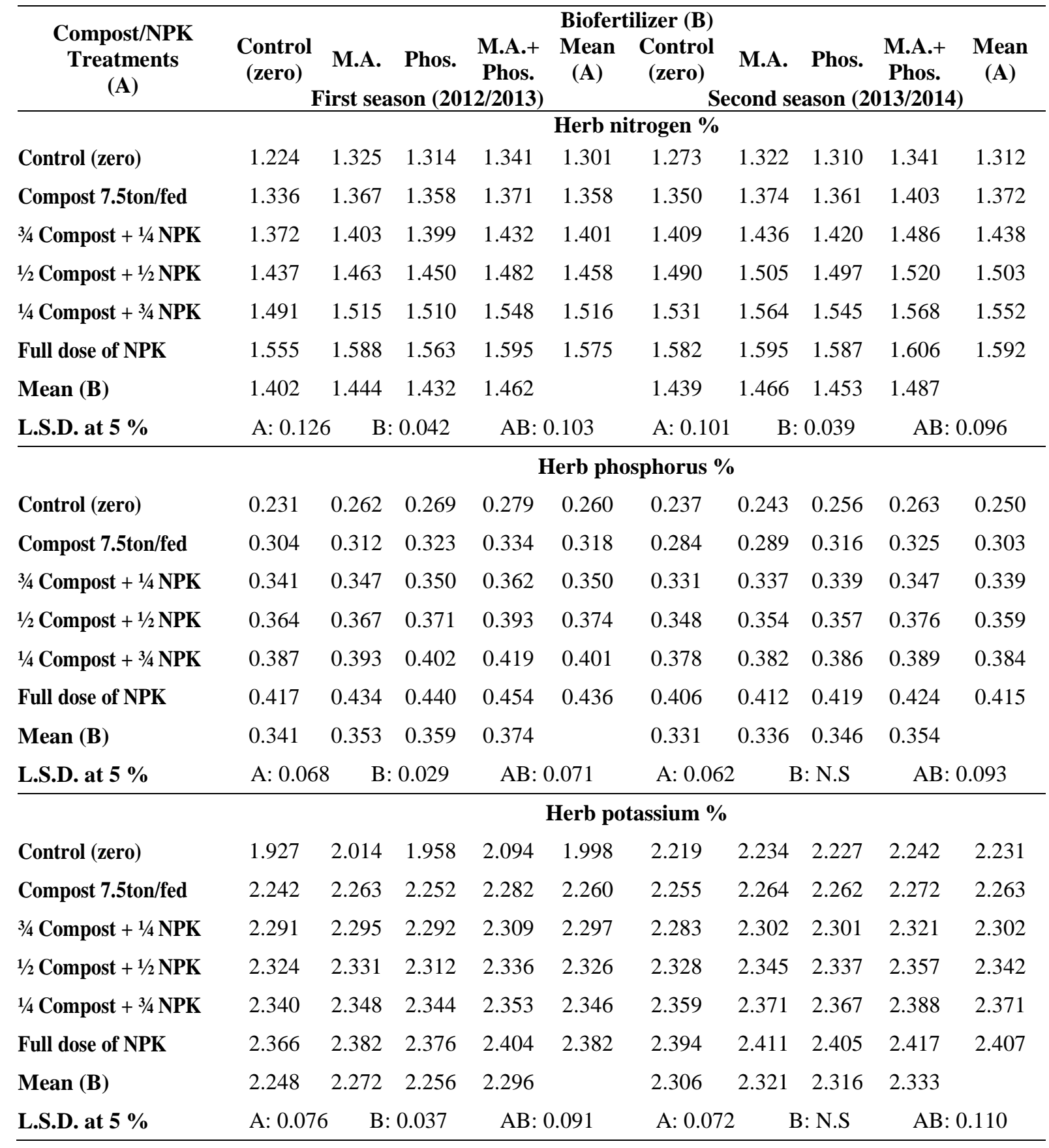




\section{F.S. Badran et al.}

phosphorein) gave higher values of herb $\mathrm{N}, \mathrm{P}$ and $\mathrm{K} \%$ than those given by control treatment in both seasons. Moreover, the dual biofertilization treatment surpassed each of Minia Azotein and phosphorein treatments. Meanwhile, phosphorein treatment gave the least values for the three nutrients in both seasons as shown in Table (3).

In accordance with these results were those found by Abd El-Latif (2002) and Abd-Enaeem (2008) on caraway; Shalateet (2006) on cumin and Tanious (2008) on fennel.

The interaction between compost/ NPK and biofertilization treatments was significant in the two experimental seasons for $\mathrm{N}, \mathrm{P}$ and $\mathrm{K} \%$ in the herb, as shown in Table (3). The highest overall values of $\mathrm{N}, \mathrm{P}$ and $\mathrm{K}$ herb percent, in the two seasons, were obtained when fennel plants were fertilized by full dose of NPK in combination with the dual biofertilization treatment.

\section{DISCUSSION}

The recommended dose of mineral NPK was applied to fennel plants to be compared with some organic and (N-fixing and/or $\mathrm{P}$ dissolving bacteria) commercial products (Minia azotein and/or phosphorein). It was found that NPK treatment overcame such compost and biofertilization treatments in growth, fruit yield NPK percent. The superiority of mineral NPK fertilization could be attributed to the unique biological and physiological roles of each one of such three essential elements in plant growth and development explained by Yagodin (1984).

Nitrogen is a constituent of most organic compounds i.e. amino acids, nucleic acids (RNA and DNA) enzymes, alkaloids, vitamins, phosphatides, purine, and many energy transfer materials such as chlorophylls, ADP and ATP, Bidwall (1974). Phosphorus which has been called the key to life is essential for cell division and for development of meristimatic tissue and it is very important for carbohydrate transformation due to multitude of phosphorylation reaction and to energy rich phosphate bond, (Lambers et al., 2000). Potassium is important for growth and elongation probably due to its function as an osmoticum and may react synergistically with IAA; moreover, it promotes $\mathrm{CO}_{2}$ as simulation and translocation of carbohydrates from the leaves to storage tissues (Mengel and Kirkby 1987).

The beneficial physiological and biological roles of organic fertilization concluded by many investigators as follows:

- Organic manure led to minimizing the losses of nutrients by leaching, (Saber, 1997).

- Adding organic manure to the soil led to significant increase in microbial activities in the root zones, (Taiwo et al., 2002).

- Incorporation of organic manure in the soil improves soil permeability and release carbon dioxide and certain organic acids during decomposition, (Mashali, 1997). Different authors such as Hedge et al. (1999) and Hauwaka (2000) explained the roles of $\mathrm{N}$ - fixing bacteria in:

- Fixation of the atmospheric $\mathrm{N}$ which caused an increment of available $\mathrm{N}$ which increase, by sequence, the formation of many metabolites.

- It produces adequate photo hormones such as indoleacetic acid, gibberellins and cytokinins.

- Enhancing the uptake of different nutrients and improving water status which leads to stimulating the meristimatic activities of cells and tissues, thereby promoting vegetative growth aspects. The enhancing effects of P- dissolving bacteria, on the other hand, were suggested by AbdouElnour et al. (1996) and Hauwaka (2000) and could be summarized in:

- Releasing some organic and inorganic acids, as well as $\mathrm{CO}_{2}$ which are capable of converting tricalcium phosphate (insoluble form) in monocalcium phosphate which is readily available for plant nutrition. 
- Increasing phosphorus concentration in the soil and plant tissues and improving water use efficiency and uptake of minerals.

\section{REFERENCES}

Abd El-Latif, T.A.T. (2002). Effect of organic manure and biofertilizer and caraway plants (Carum carui, L.). J. Agric. Sci. Mansoura Univ., 27(5):34593468.

Abd El-Naeem, L.A. (2008). Response of Caraway Plants to Some Organic and Biofertilization Treatments. M.Sc. Thesis, Fac. Agric. Minia Univ.

Abdalla, M.Y. (2009). Effect of organic, bio and mineral fertilization on growth, yield, oil productivity and chemical constituents of coriander plant. J. Agric. Sci. Mansoura Univ., 34(5):5195-5708.

Abdou-EInour, E.A.A; El-Sayed, A.A. and EI-Bendary, A.A. (1996). Effect of phosphate biofertilizer (phosphorein) on growth, yield and nutrient uptake of faba bean plants. J. Agric. Sci. Mansoura Univ., 21(2):477-483.

Badran, F.S. and Aly, M.K. and Abd ElLatif, M.Z. (2012). Influence of NPK, biofertilizers and micronutrients on Nigella sativa, L. plants. Minia Inter. Conf. for Agric \& Irrig. In the Nile Basin Countries, March 26-29, 2012, Minia, Egypt.

Badran, F.S. and Safwat, M.S. (2004). Response of fennel plants to organic manure and bio-fertilizers in replacement of chemical fertilization. Egypt J. Agric. Res., 82(2).

Badran, F.S.; Aly, M.K.; Hassan, E.A. and Shalatet, Sh.G. (2007). Effect of organic and biofertilization treatments on cumin plants. The third Conf. of Sustainable Agric. Dev. Fayoum, Egypt, Nov. 12-14, 2007:371-380.

Badran, F.S.; Attia, F.A. and Ayyat, A.M. (2011). Response of coriander (Coriandrum sativa, L.) plants, grown in new reclaimed land, to NPK fertilization and antioxidant treatment. Inter. Conf. on Total Quality Management of Herb \& Medicinal Plants and their products, Egypt, Inter. Center for Agric. Egypt, Dec. 6-8, 2011.

Badran, F.S.; Attia, F.A.; Ahmed, E.T. and Soliman, H.S. (2003). Effect of chemical and biological fertilization on growth, yield and oil production of anise (Pimpinella anisum, L.) plants. I. Effect of different potassium and phosphorus fertilization rates. Proc. $1^{\text {st }}$ Egypt \& Syr. Conf. for Agric. \& Food, Minia: Dec. 811, 2003, 1(1):103-112.

Badran, F.S.; Safwat, M.S. and Zayed, G.A. (2001). It is possible to supply fennel plants with organic- and bio- fertilizers in replacement of mineral fertilizers? ElSalam canal symposium, North Sinai, Egypt, May 7-10- 2001.

Bidwall, R.G. (1974). Plant Physiology. Macmillan Publishing Co. Inc., New York, U.S.A.

Chapman, H.D. and Pratt, P.F. (1975). Methods of Analysis for Soil, Plant and Water Calif. Univ. Division of Agric. Sci., 172-174.

Cottenie, A.; Verloo, M.; Velghe, M. and Camerlynck, R. (1982). Chemical Analysis of Plant and Soil. Laboratory of Analytical and Agro Chemistry. State Univ., Ghent, Belgium.

Hassan, E.A.; Ali, E.F. and Ali, A.F. (2010). The enhancement of plant growth, yield and some chemical constituents of dill (Anethum graveolens, L.) plants by filter mud cake and potassium treatments. Australian J. of Basic and Applied Sci., 4(5):948-956.

Hauwaka, F.I. (2000). Effect of using single and composite inoculation with Azospirillum brasilense, Bacillus megatherium var., phosphaticum and Glomus marcocarpus for improving growth of Zea mays. J. Agric. Sci., Mansoura Univ., Egypt, 25(1):239-252. 


\section{F.S. Badran et al.}

Hedge, D.M.; Dwivedi, B.S. and Sudhakara B.S.S. (1999). Biofertilizers for cereal production in India, A review. Indian J. Agric. Res., 69(2):73-83.

Kenawy, A.G. (2010). Response of Ammi visnaga, L. Plants to Some Organic and Bio-fertilization Treatments. Ph.D. Thesis, Fac. Agric., Minia Univ.

Khattab, M.E. and Helmy, L.M. (2003). Productivity and yield quality of fennel plants as affected by foliar application with some amino acids. J. Agric. Sci. Mansoura Univ., 28(5):3893-3909.

Lambers, H; Chapin, F.S. and Pons, T.L (2000). Plant Physiological Ecology. Springer-Verleg, New York Inc.

Mahmoud, S.A.E. (2009). Comparative Study on Black Cumin (Nigella sativa, L.) Plants Grown Under Different Spacing and Fertilization Treatments. M.Sc. Thesis, Fac. Agric. Assuit Univ.

Mashali, A.M. (1997). FAO global network on integrated soil management for sustainable use of salt affected soils. Proc. Inter'n Symp. On sustain. Manag. of Salt Affected Soils in the Arid Ecosystem, Sep. 21- 26, Cairo, Egypt, 31-51.

Mengel, K. and Kirkby, A. (1987). Principles of Plant Nutrition. $4^{\text {th }}$ Ed. International Potash, Institute, Bern/Swizerland.

MSTAT- C, (1986). A software program for the design, management and analysis of agronomic research experiments. (Version 4.0) Michigan State University.

Rekaby, A.M. (2013). Improving the Productively of Coriander Plants by The Use of Some Unconventional Treatments. Ph.D. Thesis, Fac. Agric. Minia Univ.

Saber, M. S. (1997): Biofertilized Farming System. Proc. Of the Training Course on Bio-Organic Farming Systems for Sustainable Agric.: 16-72.
Safwat, M.S. and Badran, F.S. (2002). Efficiency of organic and biofertilizers, in comparison with chemical fertilization, on growth, yield and essential oil of cumin plants. Proc. $9^{\text {th }}$ Conf. of Medicinal and Aromatic Plants, Cairo Egypt.

Salah-Eldeen, R.M. (2005). Effect of Planting Density and Chemical Biofertilization on Vegetative Growth, Yield Oil and Chemical Composition of Fennel (Foeniculum vulgare, Mill) Plants. Ph.D. Thesis, Fac. Agric., Minia Univ.

Seghatoleslami, M. (2013). Effect of water stress, bio-fertilizer and manure on seed and essential oil yield and some morphological traits of cumin, Bulgarian Journal of Agricultural Science, 19 (No. 6) $2013,1268-1274$.

Shalateet, Sh.G. (2006). Comparative Studies on Cumin Productivity Grown Under Traditional and Organic Cultivation Systems. M.Sc. Thesis, Fac. Agric., Minia Univ.

Taiwo, L.B.; Adediran, J.A.; Ashaye, O.A.; Odofin, O. and Oyadoyin, A.J. (2002). Organic okrr (Abdolmoschus esculentus): Its growth, yield and organoleptic properties. Nutrition \& Food Sci., 32(415):180-183. (Hort. Abst., 72(12):10918)

Tanious, C.T. (2008). Effect of Some Organic and Biofertilization Treatments on Fennel Plants. M.Sc. Thesis, Fac. Agric. Minia Univ.

Wilde, S.A.; Covey, R.P.; Lyer, J.C. and Voigt, G.K. (1985). Soil and Plant Analysis for Tree Culture. Oxford, IBH. Publishing Co., New Delhi, India.

Yagodin, B.A. (1984). Agricultural Chemistry, Part II. Publishers, Moscow, 1-66. 


\section{تأثثير معاملات التسميد بالكمبوست/ المعدني والتسميا الحيوي

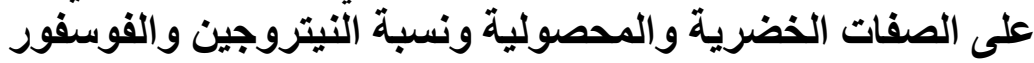

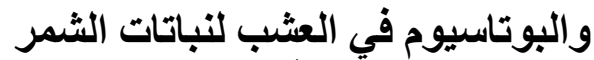

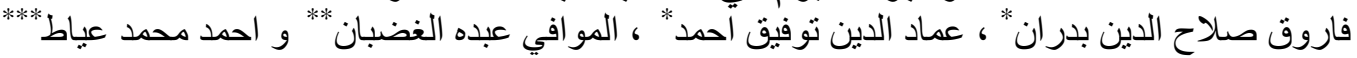
* ق قسم البساتين، كلية الزر اعة، جامعة المنيا، مصر.

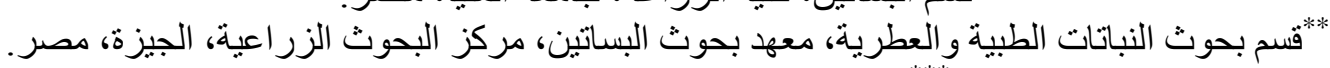

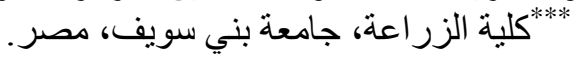

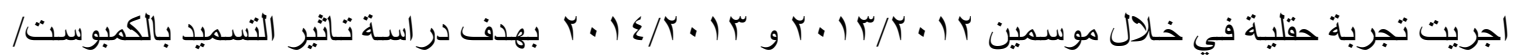

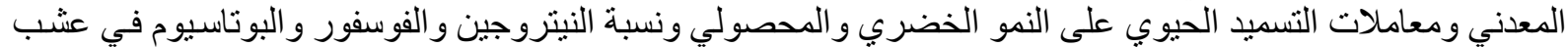
نبات الثمر.

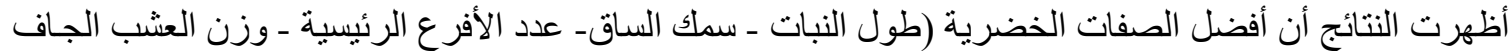

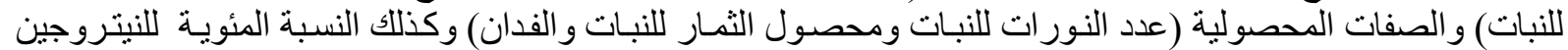

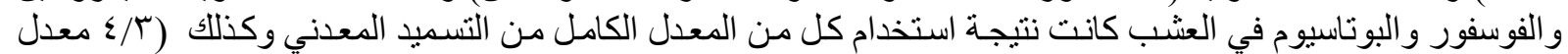

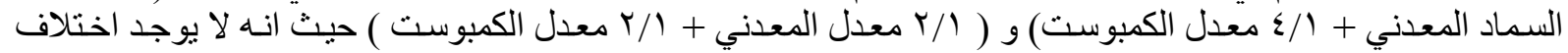

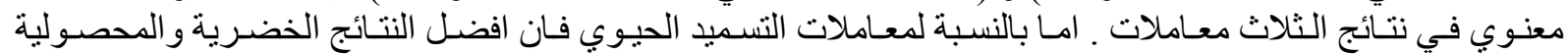

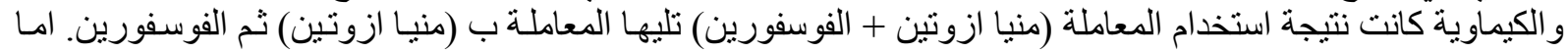

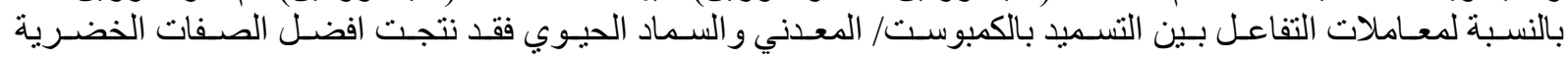

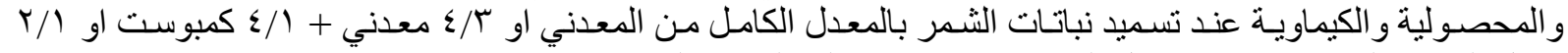

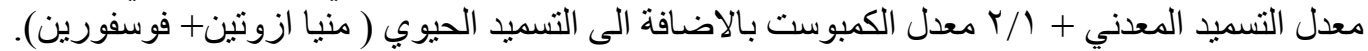

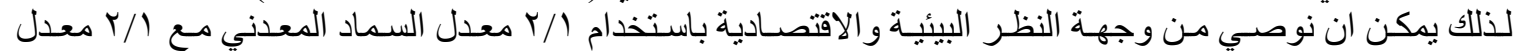
الكمبوست بالاضافة الي التسميد الحيوي (منيا ازوتين+ فوسفورين) للحصول على افضل محصول ثمار لنباتات الثمر. 
